\title{
Design of a Field Deployable Real-Time Electronic Sensor Array Based on Metal-Oxide Semiconductor: Application for Pungency Detection in Green Chillies
}

\author{
Subodh Kumar Panda', Rekha $\mathrm{P}^{2}$ and Bindu $\mathrm{S}^{3}$ \\ ${ }^{1}$ Department of Electronics \& Communication Engineering, BNM Institute of \\ Technology, Visvesvaraya Technological University, Karnataka 560070, India, \\ ${ }^{2}$ Department of Electronics \& Communication Engineering, BNM Institute \\ of Technology, Visvesvaraya Technological University, Karnataka, 560070 India \\ ${ }^{3}$ Department of Electronics \& Communication Engineering, BNM Institute of \\ Technology, Visvesvaraya Technological University, Karnataka,560070 India
}

\section{ABSTRACT}

Pungency in chillies has been rewarded great response due to its close relationship with health and safety of human being and different methods of quality evaluation have engrossed much curiosity in researchers. In this report, an low-cost and extremely sensitive sensor array for the identification and estimation of pungency in green chillies has been designed. The pungency assessment MOS array was based on a metal-oxide semiconductor device (MOS) and a comparison with chemical evaluation results. The designed MOS sensor array is tested by classifying the pungency in different types of green chillies. Experimental results confirm the efficiency of the proposed methods (chemical and MOS method).

KEY WORDS: GREEN CHILLIES, METAL-OXIDE, PUNGENCY, SENSOR ARRAY.

\section{INTRODUCTION}

Chillies are very popular vegetable around the world because of its culinary and economic value. Two major quality attributes of chillies are its aroma and pungency which are characterized by many chemical compounds present in it. Pungency in chilli is important because it decides its comparative price in market as well as export quality. Pungency in chilli fruit is caused by mainly capsaicin and dihydrocapsaicin (Marla S. et al., 2014; Maria de et al., 2011). Pungency in chillies is evaluated

\section{ARTICLE INFORMATION}

*Corresponding Author: subodhpanda2013@gmail.com Received 19th Oct 2020 Accepted after revision 26th Dec 2020 Print ISSN: 0974-6455 Online ISSN: 2321-4007 CODEN: BBRCBA

Thomson Reuters ISI Web of Science Clarivate Analytics USA and Crossref Indexed Journal

\section{1) Clarivate}

NAAS Journal Score 2020 (4.31)

A Society of Science and Nature Publication,

Bhopal India 2020. All rights reserved.

Online Contents Available at: http//www.bbrc.in/

Doi: $h t t p: / / d x . d o i . o r g / 10.21786 / b b r c / 13.13 / 1$ using organoleptic test with its Scoville Heat Unit (SHU) (Estrada B. et al.,2002; Varindra P. et al.,2008). The organoleptic test is an old and subjective test which does not take into account the aroma in chillies. Even today, the shape, size, colour, aroma and pungency of chillies at the market places are checked manually by buyers through olfactory and visual perception to assess the quality. Even though chillies have high economic value and are mainly consumed for its culinary value. Capsaicin in chillies is used in many drug preparations for treating cold, infection in throat, congestion in chest and skin ointments.

In chillies capsaicin is stored in all parts, maximum capsaicin is stored in placenta (Alberto González-Zamora et al., 2013). While measuring hotness, the physico-chemical properties of capsaicin can influence sensing depending on test conditions (Emmanuelle S. et al., 1998). Major analytical methods to measure pungency of capsaicinoids 
include Chromatography, Spectrometer techniques and recently developed CNT-based electrochemical sensors for quantifying of capsaicin (Amelia B. et al., 2015). Measurement of hotness and aroma are mainly uses different analytical techniques like chromatography and spectrometry.etc, which need expensive instrumentation and are time consuming.

Analytical methods to measure hotness in chillies are expensive and are not suitable for field deployment.The term "electronic nose" (E-nose) is frequently associated with the detection of aromas with an electronic sensor. The application of E-nose is in food and beverages industry for determination of freshness, contamination, adulteration of wide range of food products like alcoholic and non alcoholic drinks, fruits, vegetables, dairy products, olive oils etc.
E-nose available in the market consists of physical sensor array having partial specificity and customized pattern recognition tool, capable of recognizing different types of odor (Figen K. et al., 2002). An E-nose has been to evaluate pepper samples by headspace volatiles and were analyzed using discriminate function analysis (DFA). Liljana worked on classification of pepper varieties using E-nose technique and an accuracy of 91\% was obtained (Liljana. K. G. et al., 2013). Though the electronic nose has been used for measuring quality of certain vegetables and only a single case been reported for measuring quality of ground red peppers using E-nose. Thus there is scope to explore new technique for evaluating chillies, a very important cash crop. The electronic nose are strong drivers to apply it in the field of olfaction because alternatives are either too costly, like HPLC or time-consuming, e.g., human test panels.

\begin{tabular}{|l|c|c|c|c|}
\hline \multicolumn{2}{|c|}{ Table 1. MOS sensors selected for sensor array, type, specificity and detection limit } \\
\hline Sl. No. & MOS Sensor & Type & Specificity & $\begin{array}{c}\text { Detection } \\
\text { limit (ppm) }\end{array}$ \\
\hline 1 & MQ2 & Tin Dioxide $\left(\mathrm{SnO}_{2}\right)$ & $\begin{array}{c}\text { LPG, i-butane, propane, } \\
\text { methane, alcohol, } \\
\text { hydrogen and smoke }\end{array}$ & $100-20000$ \\
\hline 2 & MQ3 & Tin Dioxide $\left(\mathrm{SnO}_{2}\right)$ & Alcohol & $25-5000$ \\
\hline 3 & MQ4 & Tin Dioxide $\left(\mathrm{SnO}_{2}\right)$ & $\begin{array}{c}\text { Methane and } \\
\text { natural gas }\end{array}$ & $200-10000$ \\
\hline 4 & MQ6 & Tin Dioxide $\left(\mathrm{SnO}_{2}\right)$ & $\begin{array}{c}\text { LPG, i-butane and } \\
\text { propane }\end{array}$ & $200-10000$ \\
\hline 5 & MQ7 & Tin Dioxide $\left(\mathrm{SnO}_{2}\right)$ & Carbon monoxide & $10-500$ \\
\hline 6 & MQ9 & Tin Dioxide $\left(\mathrm{SnO}_{2}\right)$ & $\begin{array}{c}\text { Methane, propane and } \\
\text { Carbon monoxide }\end{array}$ & $10-10000$ \\
\hline 7 & MQ135 & Tin Dioxide $\left(\mathrm{SnO}_{2}\right)$ & $\begin{array}{c}\text { Ammonia, sulfide and } \\
\text { benzene }\end{array}$ & $10-10000$ \\
\hline
\end{tabular}

Figure 1: Experimental set up for measuring volatiles of green chilli using sensor array

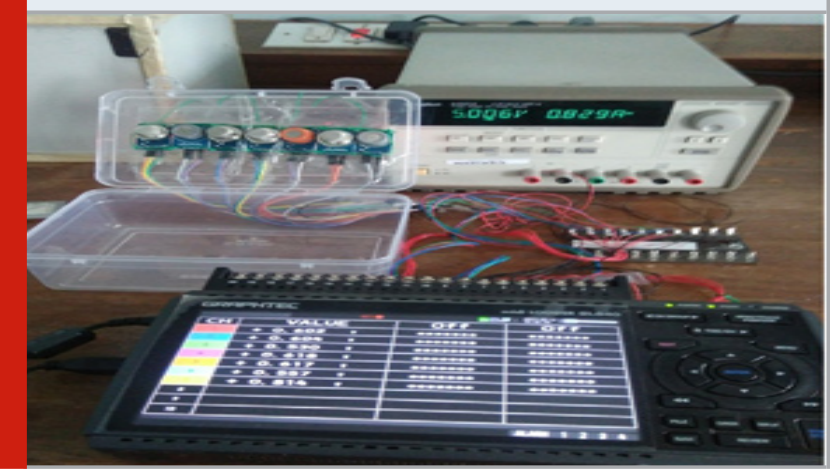

Metal oxide semiconductor (MOS) sensors that are readily available commercially are most widely used in making sensor array for odor sensing in E-nose. The active sensor film in these sensors could be Titanium dioxide (TiO2), Zinc Oxide ( $\mathrm{ZnO}$ ), Tungsten Oxide (W03) or Tin dioxide (Sn02) which is doped with a small amount of catalytic metal such as palladium or platinum. The resistance of film changes when exposed to chilli volatiles and based on resistance changes a particular variety of chilli can be identified. Further this change in resistance can be calibrated to SHU of chillies. In this work, applicability of E-nose (MOS sensor array) for evaluating quality of green chillies has been made and a prototype is developed.

\section{MATERIAL AND METHODS}

All chemicals and solvent used were purchased from Merck of analytical grade. Three varieties of fresh green chillies are obtained from local market, Bengaluru, India. Different morphology of chillies are selected for experiments, which may have different quantity of aroma as well as pungency. The local names of the three varieties of chillies are Akash, Haveri and Menasinakai. The green chilli was reduced to paste using mortar. One gram of fine paste of green chilli was subjected to solvent extraction with methanol at room temperature for 10 minutes. The extracts were concentrated by sonication at $50{ }^{\circ} \mathrm{C}$ for $20 \mathrm{~min}$. The extract was stored at $4{ }^{\circ} \mathrm{C}$ for future use. The working solution containing $0,20,40$, $60,80,100,200$ and $300 \mu \mathrm{L}$ of different analyte were 
transferred into a series of separate $2 \mathrm{~mL}$ calibrated flasks using a micropipette. The solution was diluted to $2 \mathrm{~mL}$ with methanol and mixed well.

The selection of MOS sensors was primarily based on chemical specificity and sensitivity. The other parameters considered for selection of MOS sensor comprised of size, cost and power.

Commercially MOS sensor array is not existing for detecting volatiles released by chillies. Hence, different MOS sensors sensitive to volatile organic compounds (VOCs) are choosen. Chillies volatiles primarily contain compounds belonging to aromatic series which are measured by sensor array. Selection of sensors is done from a set of commercial off-the-shelf MOS sensors (MQ Series) which are used for detecting alcohols, cooking gas, methane, natural gas, sulfide, ammonia, carbon monoxide and benzene etc as shown in Table 1 and a sample data sheet of MQ3 is shown in reference (Krupa Karuna Vani, B. 2017). An array of seven sensors is used for detection of volatile components in chilli.

Figure 2: MQ sensors basic test circuit

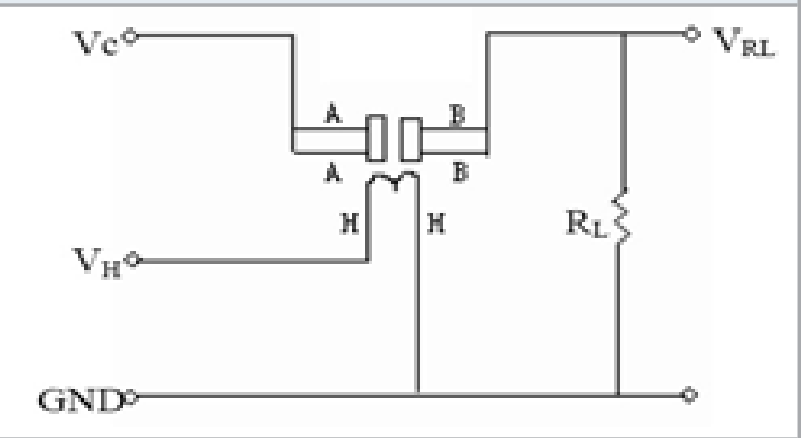

Experimental setup for measuring concentration of volatiles is shown in Figure 1. Sensor array is fixed at the top of a sealed plastic chamber of volume 1056 $\mathrm{cm} 3(\mathrm{~L}=16 \mathrm{~cm}, \mathrm{~W}=11 \mathrm{~cm} \& \mathrm{H}=6 \mathrm{~cm})$. Sensors are powered from Agilent E3631A triple output power supply. Sensor output voltages taken through feed through are connected to a Graphtec data logger (midi logger GL840) and data is collected by a DELL desktop.

When sensors are powered on, sensor output voltage reduces as temperature of the sensor increases due to heating. The sensor array is kept $\mathrm{ON}$ for a pre-heating time of 2 hours till resistance variation is within $\pm 2 \%$ in 15 minutes which is taken as baseline voltage. After stabilization of the output voltage the chilli sample to be tested is introduced into the chamber and the sensor array response is measured for another 15 minutes. Following this the chamber cover is opened and the sensor array is allowed to recover with the heaters ON. The heaters are kept $\mathrm{ON}$ throughout the experiment for the day to avoid preheating before every experiment in the day. The chilli sample introduced into the chamber gives out aroma/pungent compounds on to the head space of the chamber and adsorbs on to the surface of sensors in the array. Depending on the sensitivities of each sensor to 03 the composite vapours in the head space each sensor will respond differently. The sensor responses are measured by the data logger as change in voltage with time.

Basic Measuring Circuit: Sensor element is connected between Vc and VRL and load resistance RL is internally connected across which output voltage is taken. Heater of $750 \mathrm{~mW}$ at $5 \mathrm{~V}$ is connected between VH and GND for heating the sensor element. The sensor resistance can be calculated using the formula given below,

$$
\mathrm{Rs}=\left(\frac{\mathrm{v}_{\mathrm{C}}}{\mathrm{v}_{\mathrm{R}_{\mathrm{L}}}}-1\right) \times \mathrm{R}_{\mathrm{L}}
$$

Change of resistance of sensor film due to adsorption of volatiles is measured by change $n$ voltage across RL which is proportional to concentration.

Quantitative Analysis: Twenty gram of green chilli, cut vertically and kept on a glass plate such that the cut side faces up, is kept inside the chamber after opening it for a short time and then closed. Sensor array responses are recorded for about 10 to 15 minutes and then the chamber is opened for recovery. Once a particular type of fresh green chilli testing is over, the chamber is kept open for a minimum of 2 hours for the sensors to recover and the chamber is clear of all volatiles. The chamber is closed with sensors powered for one more hour to have good recovery of sensors and good repeatability of results before start of another measurement. All experiments are conducted at room temperature.

Figure 3: Plot of percentage $(\Delta \mathrm{V} / \mathrm{V})$ vs. time when senso array is exposed to 20-gram of Akash green chilli

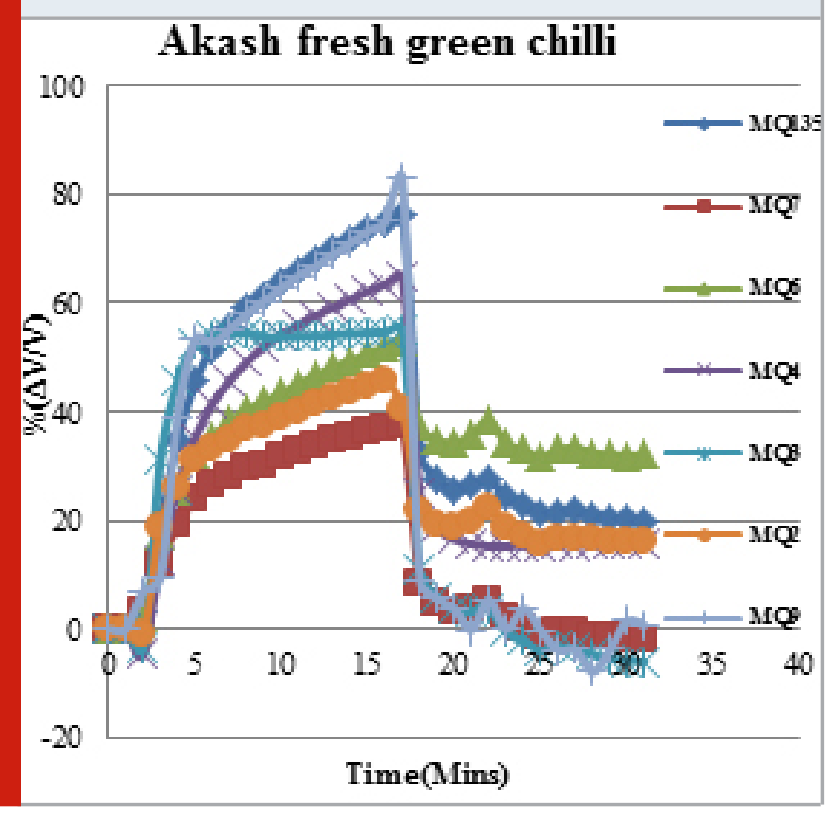

RESULTS AND DISCUSSION

The response of sensor array with respect to time to the Akash green chilli is shown in Figure 3. Twenty gram 
of fresh cut chilli is kept inside the chamber and the response of sensors is measured as $(\Delta \mathrm{V} / \mathrm{V})$ as a percentage where, $\mathrm{V}$ is the base value and $\Delta \mathrm{V}$ is the change from base value.

Figure 4: Plot of percentage $(\Delta \mathrm{V} / \mathrm{V})$ vs. time when sensor array is exposed to 20-gram of Haveri green chilli

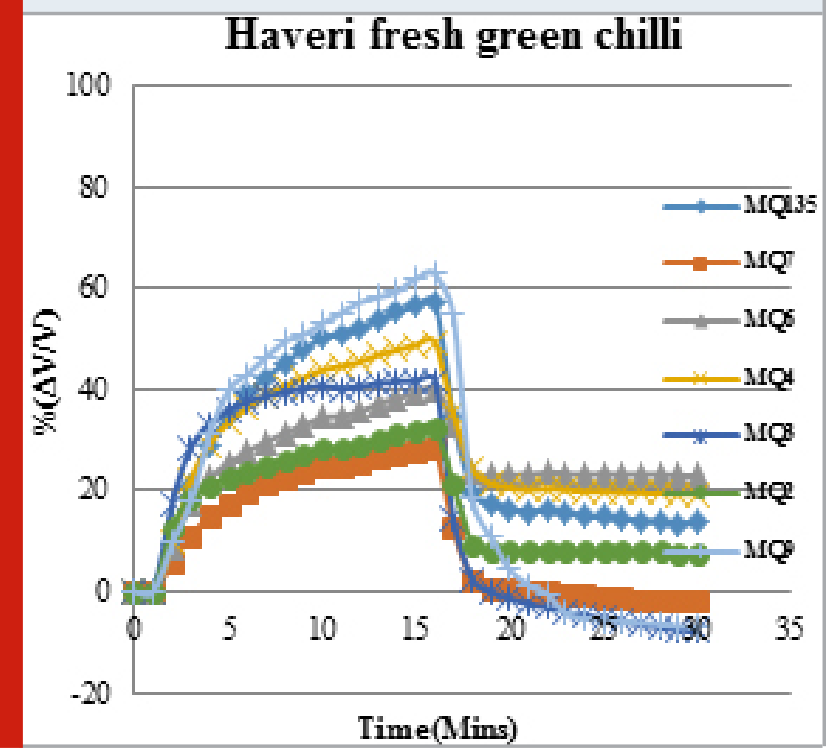

Figure 5: Plot of percentage $(\Delta V / V)$ vs. time when sensor array is exposed to 20-gram of Menasinakai green chilli

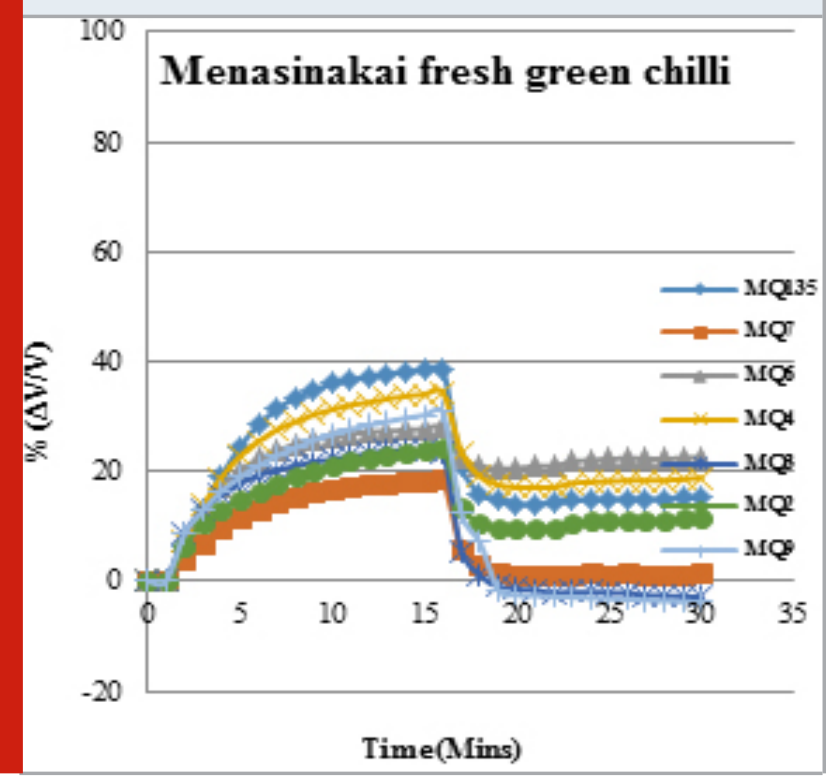

A maximum sensitivity of 38.56 percentages is shown by MQ135 and a minimum of $18.47 \%$ is seen for MQ7. However, among three varieties of chillies MQ7 shows consistently lower sensitivity. The response of sensor array for three varieties of green chillies is compared in the bar chart in Figure 6. From Figure 6, it is observed that all the sensors follow a particular pattern, Akash green chilli shows maximum sensitivity for all sensors, followed by Haveri and finally Menasinakai (bhaji chilli). A radar plot for $\%(\Delta V / V)$ is shown in Figure 7.
Out of the seven sensors maximum change is shown by MQ9 sensor, $(\Delta \mathrm{V} / \mathrm{V})$ by $82.2 \%$ where as MQ7 sensor shows a minimum change of $37.55 \%$, in 15 minutes. The response of sensor array to the Haveri green chilli with respect to time is shown in Figure 4. A maximum sensitivity of 62.81 percentage is shown by MQ9 sensor where as a minimum. of $28.35 \%$ is shown by MQ7 sensor in 15 minutes. The responses of different sensors are similar to Akash chilli but the sensitivity is less. The response of the sensor array to Menasinakai green chilli with respect to time is shown in Figure 5.

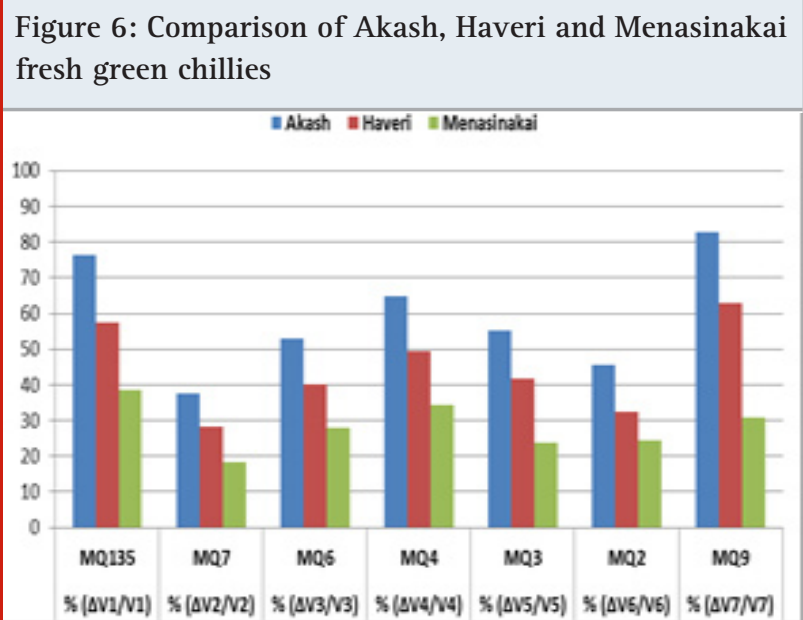

Figure 7: Radar plot showing $\%(\Delta V / V)$ variation of three varieties of fresh green chillies

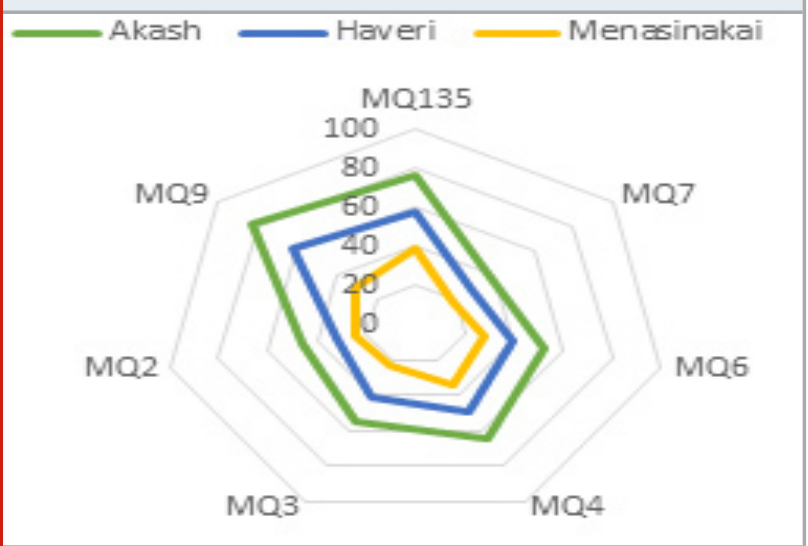

The observation made from the bar chart can be more easily seen from radar plot of Figure 7 . The total area covered, represents the sum of responses due to all seven sensors. Akash chilli has covered maximum area compared to Haveri followed by Menasinakai. The total area covered may be thought to represent total volatile components present in chillies. The area of the radar plot is proportional to the sum of the values of the sensor array responses which are given in Table 2 .

Absorption Analysis: Generally the quantity of capsaicin in chilli is measured by HPLC method which is calibrated to Scoville rating of pungency. This process is time consuming and expensive. So, some have attempted using UV spectroscopy which is relatively fast and 
easier for easuring quantity of capsaicin (Barbero G. F. et al., 2008).

Measurements of the concentration of capsaicin in the extracts were evaluated through their absorbencies measured on $\lambda=280 \mathrm{~nm}$ by UV spectrophotometer (Magaji G. et. al., 2014). UV-1800 UV-Vis Spectrophotometer with wavelength accuracy $\pm 0.3 \mathrm{~nm}(190 \mathrm{~nm}-1100 \mathrm{~nm})$

Table 2. Comparison of total sensitivity of green chillies using different MOS sensors

\begin{tabular}{|c|c|c|c|c|c|c|c|c|}
\hline \multirow{2}{*}{$\begin{array}{l}\text { Green } \\
\text { Chilli }\end{array}$} & \multicolumn{7}{|c|}{ Name of MOS sensors } & \multirow{2}{*}{$\begin{array}{c}\text { Total } \\
\text { sensitiv } \\
\text { ity* }\end{array}$} \\
\hline & $\begin{array}{l}\text { MQ } \\
135\end{array}$ & $\begin{array}{c}\mathrm{MQ} \\
7\end{array}$ & $\begin{array}{c}\mathrm{MQ} \\
6\end{array}$ & $\begin{array}{c}\mathrm{MQ} \\
4\end{array}$ & $\begin{array}{c}\mathrm{MQ} \\
3\end{array}$ & $\begin{array}{c}\mathrm{MQ} \\
2\end{array}$ & $\begin{array}{c}\mathrm{MQ} \\
9\end{array}$ & \\
\hline Akash & $\begin{array}{l}76 . \\
37\end{array}$ & $\begin{array}{l}37 . \\
56\end{array}$ & $\begin{array}{l}52 . \\
80\end{array}$ & $\begin{array}{l}64 . \\
72\end{array}$ & $\begin{array}{l}55 . \\
09\end{array}$ & $\begin{array}{l}45 . \\
71\end{array}$ & $\begin{array}{l}82 . \\
81\end{array}$ & 415.06 \\
\hline Haveri & $\begin{array}{l}57 . \\
45\end{array}$ & $\begin{array}{l}28 . \\
35\end{array}$ & $\begin{array}{l}40 . \\
04\end{array}$ & $\begin{array}{r}49 . \\
36\end{array}$ & $\begin{array}{l}41 . \\
82\end{array}$ & $\begin{array}{l}32 . \\
52\end{array}$ & $\begin{array}{l}62 . \\
81\end{array}$ & 312.35 \\
\hline $\begin{array}{c}\text { Menasin } \\
\text { akai }\end{array}$ & $\begin{array}{l}38 . \\
56\end{array}$ & $\begin{array}{l}18 . \\
47\end{array}$ & $\begin{array}{l}28 . \\
02\end{array}$ & $\begin{array}{l}34 . \\
41\end{array}$ & $\begin{array}{l}23 . \\
83\end{array}$ & $\begin{array}{l}24 . \\
47\end{array}$ & $\begin{array}{l}30 . \\
81\end{array}$ & 198.57 \\
\hline
\end{tabular}

Table 3. Absorbance vs. Wavelength of Akash fresh green chilli

\begin{tabular}{|l|l|l|l|l|l|l|l|}
\hline $\begin{array}{l}\text { Wavelengt } \\
\text { h (nm) }\end{array}$ & \multicolumn{7}{|c|}{ Concentration in micro liter } \\
\hline & 20 & & & & & & \\
& $\mu$ & 40 & 60 & 80 & 100 & 200 & 300 \\
& $\mathrm{~L}$ & $\mu \mathrm{L}$ & $\mu \mathrm{L}$ & $\mu \mathrm{L}$ & $\mu \mathrm{L}$ & $\mu \mathrm{L}$ & $\mu \mathrm{L}$ \\
\cline { 2 - 7 }
\end{tabular}

\begin{tabular}{|l|l|l|l|l|l|l|l|}
\hline \multicolumn{1}{|c|}{ Absorbance Values } \\
\hline $664.5-665$ & $\begin{array}{l}0.0 \\
03\end{array}$ & 0.008 & 0.008 & 0.011 & 0.013 & 0.028 & 0.038 \\
\hline
\end{tabular}

\begin{tabular}{|lll|l|l|l|l|l|l|}
\hline $604.5-665$ & 03 & 0.008 & 0.008 & 0.011 & 0.013 & 0.028 & 0.038 \\
\hline $468.5-469$ & - & 0.011 & 0.013 & 0.019 & 0.023 & 0.047 & 0.067 \\
\hline $437-439$ & - & 0.014 & 0.017 & 0.024 & 0.03 & 0.061 & 0.087 \\
\hline
\end{tabular}

\begin{tabular}{|l|l|l|l|l|l|l|l|}
$437-439$ & - & 0.014 & 0.017 & 0.024 & 0.03 & 0.061 & 0.087 \\
\hline $\begin{array}{l}318.5- \\
326.5\end{array}$ & - & 0.017 & - & 0.031 & 0.041 & - & - \\
\hline
\end{tabular}

\begin{tabular}{|l|l|l|l|l|l|l|l|}
\hline $\mathbf{2 6 9 . 5 - 2 7 0}$ & $\begin{array}{l}0.0 \\
25\end{array}$ & 0.059 & 0.086 & 0.117 & 0.149 & 0.296 & 0.434 \\
\hline $200.5-204$ & $\begin{array}{l}0.2 \\
31\end{array}$ & 0.482 & 0.712 & 0.945 & 1.175 & 2.021 & 2.598 \\
\hline Total & $\begin{array}{l}0.2 \\
59\end{array}$ & 0.591 & 0.836 & 1.147 & 1.431 & 2.453 & 3.224 \\
\hline
\end{tabular}

Wave lengths at which absorbance peak occurs is affected by presence of other compounds (Reule A. G. et al., 1976). Thus the peak at $270 \mathrm{~nm}$ is because of presence of capsaicin and other due to benzene derivative. Figure and resolution of $1 \mathrm{~nm}$ is used for experimentations. In this study, experiments are conducted with different concentrations of chilli stock solution for three varieties of green chillies and plot of wavelength versus absorbance is plotted. Table 3 shows absorbance peaks of extract of Akash green chilli for various concentrations. Absorbance peak of capsaicin occurs at $280 \mathrm{~nm}$. and for benzene derivative at $204 \mathrm{~nm}$.

Figure 8: UV visible spectra of Akash chilli stock solution for different concentrations

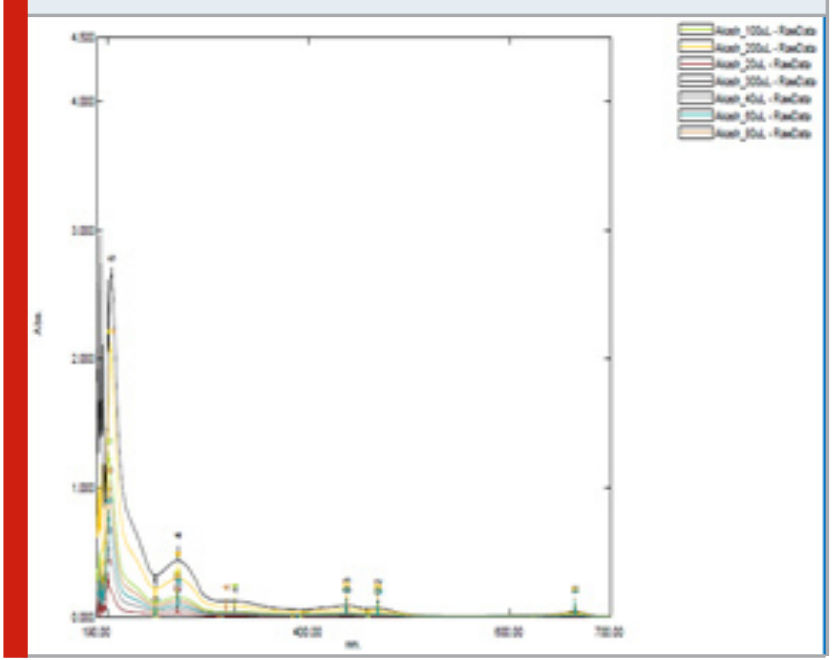

Figure 9: Plot of Absorbance at (269.5 - 270) nm Vs.

Stock solution of Akash fresh green chilli

Absorbance vs. concentration of Akash chilli stock solution (200.5-204)nm

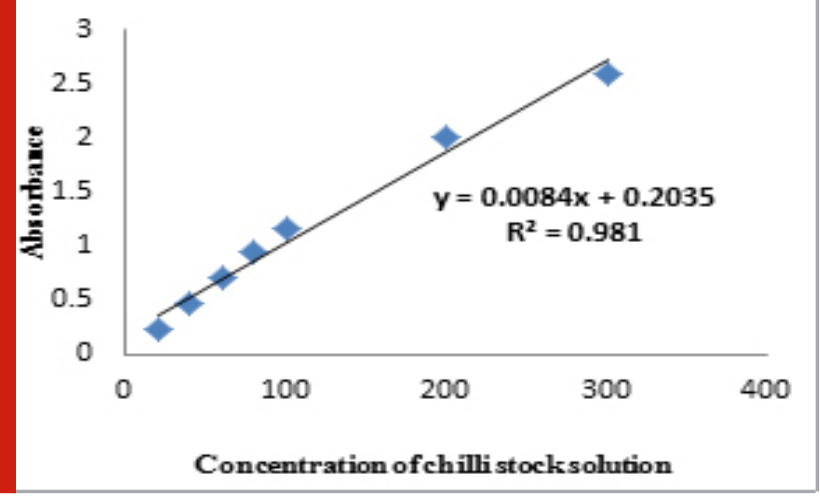

8 shows UV visible spectra for different concentrations of Akash chilli stock solution $(20 \mu \mathrm{L}, 40 \mu \mathrm{L}, 60 \mu \mathrm{L}, 80 \mu \mathrm{L}$, $100 \mu \mathrm{L}, 200 \mu$ and $300 \mu \mathrm{L})$.

Figure 9 and 10 shows, values of absorbance with concentration for three varieties of green chilli extract for two wavelengths. The absorbance is linearly proportional to both wavelengths with a regression coefficient 0.981 .

Experiments are conducted for Haveri and Menasinakai green chillies too using UV spectrum. Table 4 shows comparison of absorbance values of green chillies at 
wave length range (265 to 293.5) $\mathrm{nm}$. The SHU values of these three types of chillies were measured in a standard laboratory using HPLC for calibrating the sensor absorbance with SHU.

Figure 10: Variation of absorbance at $(200.5$ - 204) nm with concentration of extract for Akash fresh green chilli

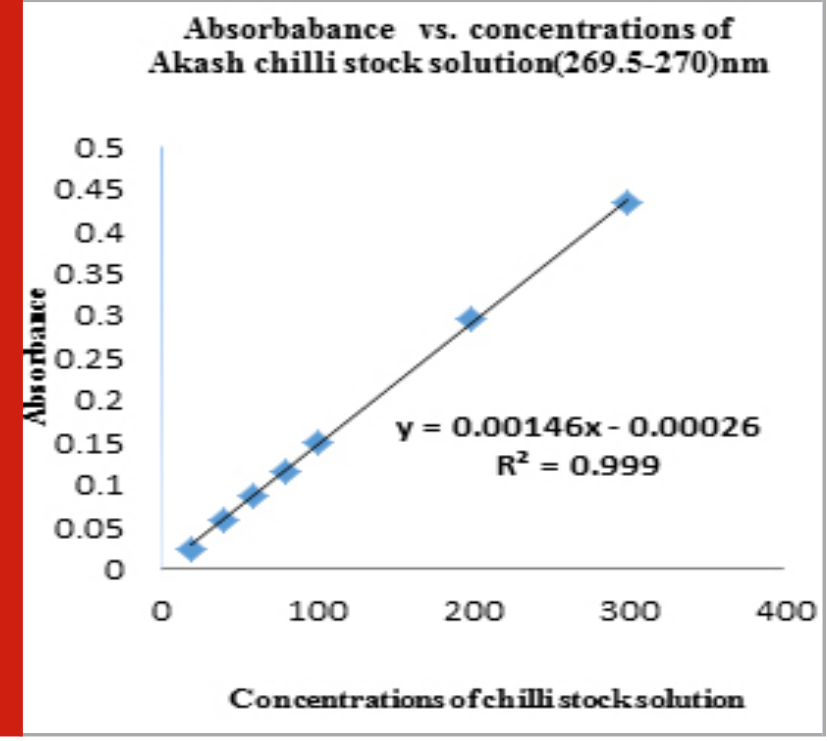

Figure 11: Plot of absorbance vs. SHU of green chilli at (265 to 293.5$) \mathrm{nm}$

Absorbance vs. SHU of green chilli at (265 to 293.5$) \mathrm{nm}$ for $300 \mu \mathrm{L}$ of stock solution

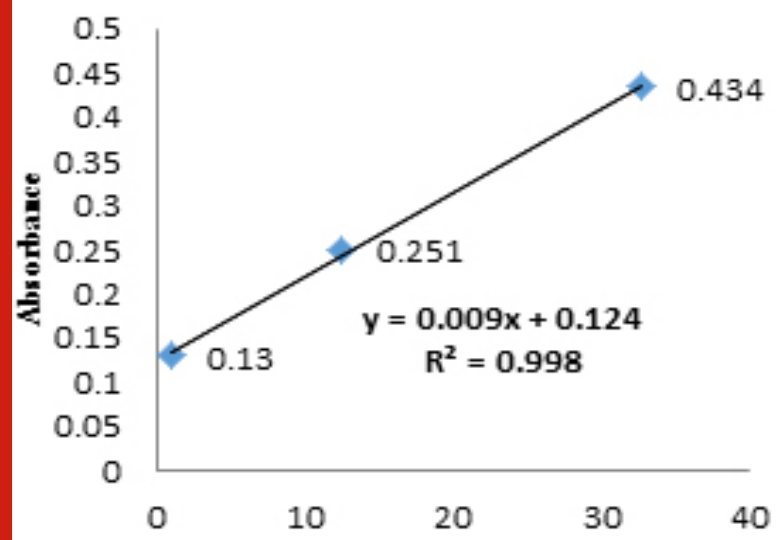

SHU in Kilo units

Figure 11, 12 and 13 shows that, the absorbance of green chilli correlates to SHU linearly for different stock solution. Table 5 shows comparison of absorbance values of 2.021, 1.753 and 0.801 for $200 \mu \mathrm{L}$ green chillies solution. Figure 14 shows the absorbance value of green chilli. The absorbance in different concentration is not linear related to SHU.
Table 4. Comparison of absorbance value of green chilli at (265 to 293.5 ) $\mathrm{nm}$ for $300 \mu \mathrm{L}, 200 \mu \mathrm{L}$ and $100 \mu \mathrm{L}$ stock

\begin{tabular}{|c|c|c|c|c|}
\hline Green & Absorbance & Absorbance & Absorbanc & SHU in \\
\hline $\begin{array}{l}\text { Chilli } \\
\text { Type }\end{array}$ & $\begin{array}{l}\text { Values } \\
(300 \mu \mathrm{L})\end{array}$ & $\begin{array}{l}\text { Values } \\
(200 \mu \mathrm{L})\end{array}$ & $\begin{array}{l}\text { Values } \\
(100 \mu \mathrm{L})\end{array}$ & \begin{tabular}{|l} 
Kilo \\
Units
\end{tabular} \\
\hline Akash & 0.434 & 0.296 & 0.149 & 32.7 \\
\hline Haveri & 0.251 & 0.157 & 0.061 & 12.5 \\
\hline Menasinaka & ai 0.13 & 0.078 & 0.025 & 1 \\
\hline
\end{tabular}

Figure 12: Plot of Absorbance vs. SHU of green chilli at (265 to 293.5) $\mathrm{nm}$ for $200 \mu \mathrm{L}$ of stock solution

Absorbance vs. SHU of green chilli at (265 to 293.5$) \mathrm{nm}$ for $\mathbf{3 0 0} \boldsymbol{\mu L}$ of stock solution

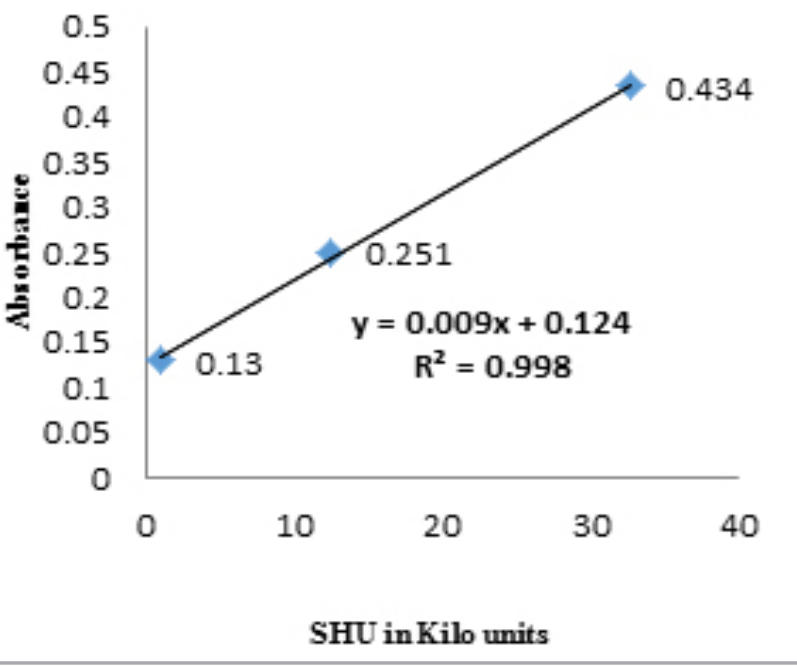

Figure 13: Plot of Absorbance vs. SHU of green chilliat (265 to 293.5) $\mathrm{nm}$ for $100 \mu \mathrm{L}$ of stock solution

Absorbance vs. SHU of green chilli at (265 to 293.5 ) $\mathrm{nm}$ for $100 \mu \mathrm{L}$ stock solution

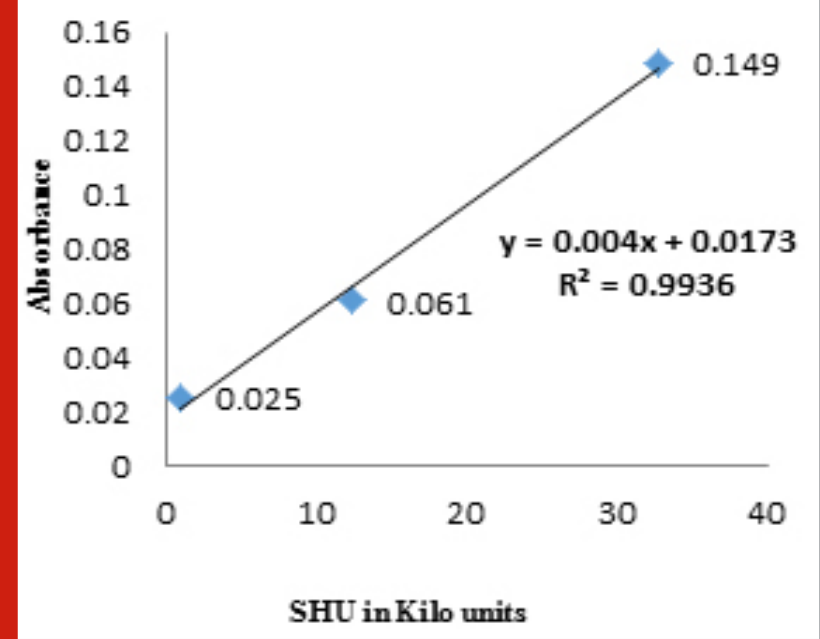


Figure 14: Plot of Absorbance vs. SHU of green chilli at (200 to 204) $\mathrm{nm}$ for $200 \mu \mathrm{L}$ of stock solution

\section{Absorbance vs. SHU of green chilli at (200 to 204$) \mathrm{nm}$ for $200 \mu \mathrm{L}$ stock solution}

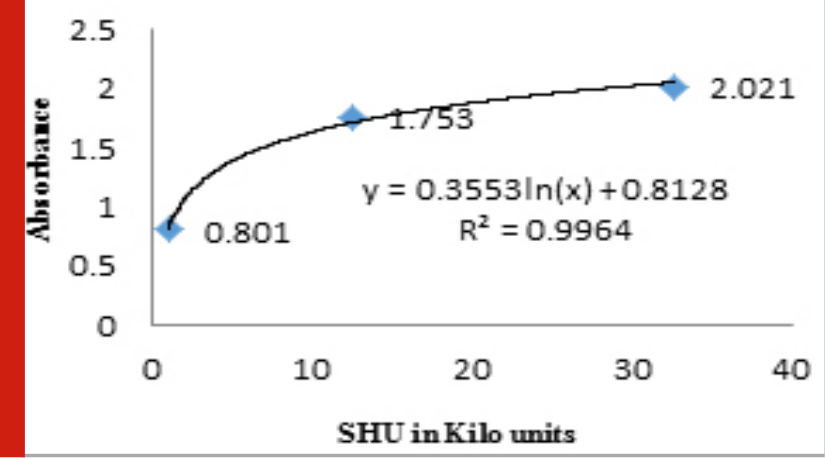

Table 5: Comparison of absorbance value of green chilli at (200 to 204) $\mathrm{nm} 200 \mu \mathrm{L}$ stock solution

\begin{tabular}{|l|c|c|c|}
\hline $\begin{array}{l}\text { Green } \\
\text { Chilli } \\
\text { Type }\end{array}$ & $\begin{array}{c}\text { Absorbance } \\
\text { Values }\end{array}$ & $\begin{array}{c}\text { SHU in } \\
\text { Kilo } \\
\text { Units }\end{array}$ & \\
\hline Akash & 2.021 & 32.7 & \\
\hline Haveri & 1.753 & 12.5 & \\
\hline Menasinakai & 0.801 & 1 & \\
\hline
\end{tabular}

Figure 15: Interfacing of sensor with LCD display and Arduino Board

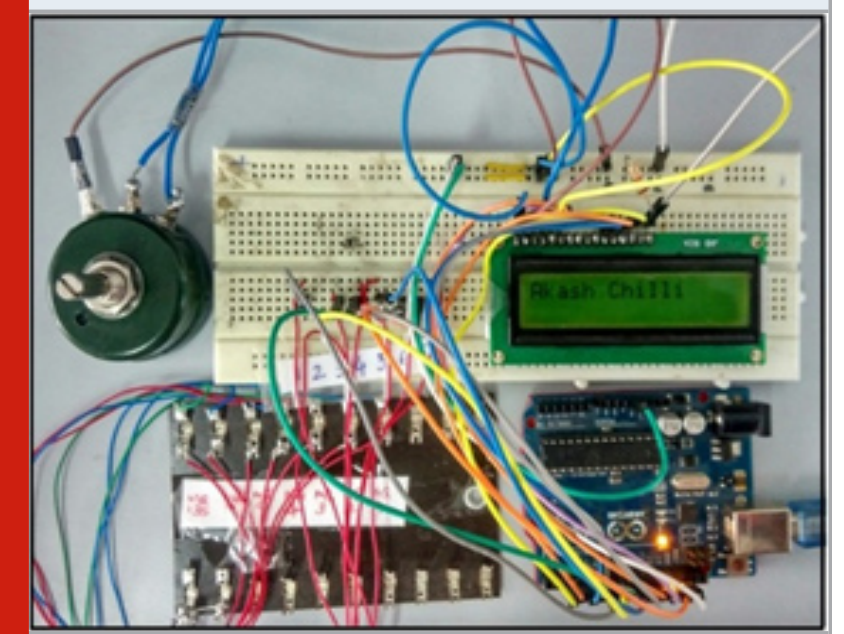

Instrument To Measure Shu and Identify Type Of Green Chilli

An instrument that could be deployed in the field for measuring the relative pungency of green fresh chilli is developed using Arduino (ATmega328 chip) board.

This instrument together with the test chamber described earlier and power supply can be deployed in the field. The Arduino board can take maximum of six sensor inputs,
So MQ7 sensor whose response is minimum, is discarded and rest six sensor data is used to calculate the $\%(\Delta \mathrm{V} / \mathrm{V})$ and sum of the responses of the six sensors to get the area pattern. The cumulative response can be calibrated to SHU after experimenting with several chillies of known SHU. This can also identify the type of chilli based on the individual responses to each sensor in the array.

\section{CONCLUSION}

Electronic olfaction device or E-nose in this context can play a vital role in grading peppers accurately. Measurements of pungency of different varieties of green chilli have been made using MOS Electronic sensor array and validated using the spectra of their extracts. The response of sensor array to green chilli correlates to the SHU linearly and it is possible to use this information for identification of the variety and measure SHU. Apart from hotness, chillies are also used for their aroma and colour. All previous work has been mostly on dry chilli and so an attempt to measure hotness of green chilli has been made. The measurements include aromatic compounds which is absent in dry chilli and contributes to true value of quality. It has been possible to find way of grading chillies at site of growth so that they can be picked at right place and time.

\section{ACKNOWLEDGEMENTS}

The authors thank management of BNM Institute of Technology, Bengaluru for carrying out this research work. Authors also thank Dr. M. S. Suresh for his guidance, suggestions, and valuable inputs during the research work.

\section{REFERENCES}

Alberto González-Zamora , Erick Sierra-Campos, J. Guadalupe Luna-Ortega, Rebeca Pérez-Morales, Juan Carlos Rodríguez Ortiz and José L. García-Hernández,: (2013) Characterization of Different Capsicum Varieties by Evaluation of Their Capsaicinoids Content by High Performance Liquid Chromatography, Determination of Pungency and Effect of High Temperature, Molecules :Vol. 18, No. 11, Pages 13471-13486.

Amelia B.(2015) Metal Oxide Sensors for Electronic Noses and Their Application to Food Analysis. Sensors, Vol. 10, No. 4, Pages 3882-3910.

Barbero, G. F., Liazid, A., Palma, M., Barroso, C. G., and Barbero, G. F., Talanta (2008) Ultrasound-assisted extraction of capsaicinoids rom peppers, Elsevier,Vol. 75,No.5, Pages 1332 - 1337.

Emmanuelle S., Jacques, O. B., and Felix, E.(1998) Electronic Noses and Their Application to Food, Food Science \& Technology, Vol. 31, No. 4, Pages 305-316. Estrada B., Bernal, M.A,, Díaz, J., Pomar, F., and Merino, F., J (2002) Capsaicinoids in Vegetative Organs of Capsicum annuum L. in Relation to Fruiting, Agric. Food. Chem.,Vol. 50, No. 5, Pages 1188-1191. 


\section{Panda et al.}

Figen K., Neriman, B., Murat, O. B., and Yasar, H.(2002) Ground Red Peppers: Capsaicinoids Content, Scoville Scores, and Discrimination by an Electronic Nose, J. Agric. Food Chem. Vol. 50, No.11, Pages 3257-3261

Liljana, K. G., Sasa, M., Viktorija, A., Dusan, S., (2013) Content of capsaicin extracted from hot pepper (Capsicum annuum ssp. microcarpum L.) and its use as an ecopesticide, Hem. Ind, Vol. 67, No. 4,Pages 671675.

Magaji, G., Usman Mohd, Y., Rafii Mohd, R., Ismail Md. Abdul, M., and Mohammad, A. L.,(2014) Capsaicin and Dihydrocapsaicin Determination in Chili Pepper Genotypes Using Ultra-Fast Liquid Chromatography, Molecules, Vol.19, Pages 6474 - 6488.

Maria de, L. R., Edith, G. G. M., and Erika, V. T.P (2011) Chemical and Pharmacological Aspects of Capsaicin, Molecules, Vol.00, No.16, Pages 1253-1270.

Marla, S., Janclei, P. C., Arlete, Marchi, T., Helena, and T. G. (2014) Food Res. Int, Vol.00, No. 64, Pages 718-
725.

Varindra P., and Sharma, S., J.(2008) Accumulation of Capsaicin in Seed, Pericarp and Placenta of Capsicum annuum L Fruit, Plant Biochem. Biotech., Vol. 23, Pages 23-27.

Krupa Karuna Vani, B.,(2017) Estimation of capsaicin content in different red chili varieties by UVspectrophotometer, Carib. J. Sci. Tech.,Vol.5, Pages 25-31.

Reule, A. G., (1976) Journal of Research of the National Bureau of Standards - A, Physics and chemistry, 609. Qinghang Ding, Dongjie Zhao , Jun liu and Zeming Yang (2018) , Detection of fruits in warehouse using Electronic nose, MATEC Web of Conferences 232, 04035 ,doi.org/10.1051/matecconf/201823204035

Jessica Roberts, Aoife Power, James Chapman, Shaneel Chandra and Daniel Cozzolino, (2018), The Use of UV-Vis Spectroscopy in Bioprocess and Fermentation Monitoring, Fermentation ,4, 18; doi:10.3390/ fermentation 4010018 